\title{
竹粉プレス戌形体の強度特性 \\ Mechanical Properties of Press Molding Products using Bamboo Powder
}

正 越智真治（宮城高锠） $\bigcirc$ 千葉洸（宮城高専）

Shinji OCHI, Miyagi National College of Technology, 48 Nodayama, Medeshima-Shiote, Natori-shi, Miyagi HIROSHI CHIBA, Miyrigi National College of Technology

Key words: bamboo powder, hof press, mechanical properties, natural fiber

\section{1. 緒言}

現在、私たちの生活を支えているのはプラスチックである と言っても過言ではないだろう. プラスチックは成形, 加工 が容易であるため，様々な用途で使用されている．しかしプ ラスチックは原油の埋蔵量減少に伴う枯渇によって, 将来的 に産業が成り立たなくなる恐れがある。また，原油価格の異 常高騰により，生活に甚大な影響を及ぼした。 さらには，地 球温暖化を始めとする環境問題が叫ばれる今日，プラスデッ クの然焼処分によって発生する二酸化炭素が温暖化の要因门 一つであるとされている. これらの問題は早急に対策を講じ る必要がある. よって原油を使用せず，なおかつ処分する際 に二酸化炭素の排出量が少ない材料の開発が必要とされる.

本研究はプラスチックの代替材料として, 竹が工業資源々 して有用かを調査することが目的である．竹は日本に群生し ている孟宗竹を使用し, 粉末化した試料 (以降, 竹紛と呼ぶ) から試験片を加熱プレスによって作製した．粉末化は竹本来. が持つ高強度の繊維構造は失われてしまうが, 工業資源とし て, 成形のしやすさは重要な因子となるため行うことにした。 竹紛を使用した成形体の強度特性として, 引張試験, 曲以、試 験を行い，プラスチックの代表的な材料である，ポリエチン ン, ポリプロピレン, ポリアセタールとの強度比較を行った。

\section{2. 実験方法}

\section{1 供試材料}

本研究では，孟宗竹の内皮を紛体にし，デジタル高制御ゔ シケーター（AS ONE， RCD-PC-P）を用いて $25^{\circ} \mathrm{C}, 50 \% \mathrm{RH}$ で保存した竹粉を使用した. Fig.1 に外観写真とマイクロスコ ープで撮影した写真を示す. 竹稈は柔細胞 (基本組織) と, 柔細胞の中を縦に通る維管束鞘で構成されている. Fig.1 かに， 粉砕された丸く細かい基本組織である柔細胞と, 細長い維管 束鞘を見ることができる. 寸法は $100 \mu \mathrm{m} \sim 1 \mathrm{~mm}$ である.

\section{2 引張試験}

試験片は JIS K 7139-1996 プラスチックー多目的試験片の4
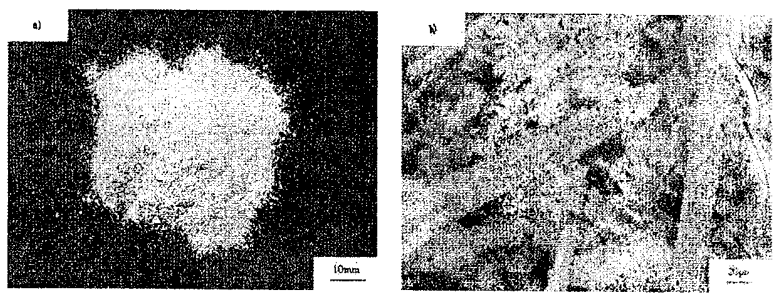

Fig.1 Photographs of bamboo powder
a) Over view
b) Microscope

形を参考にて作製した. Fig.2に作製した試験片の写真を示寸. 各部分の寸法は, 全長が $152 \mathrm{~mm}$, 平行部分の長さが $86 \mathrm{~mm}$, 平行部分の幅が $10 \mathrm{~mm}$, 厚さが $3 \mathrm{~mm}$ である. 成形温度は $150^{\circ} \mathrm{C}$, $180^{\circ} \mathrm{C}, 200^{\circ} \mathrm{C}, 240^{\circ} \mathrm{C}$, 設定圧力 $72 \mathrm{MPa}$ である.

作製した試験片を JS K 7162-1994 プラスチック-引張特性 の試験方法を参考に試験を行った，個数は，各設定温度に対 し 5 個である.試験片は荷重測定機(AIKOH ENGINEERING, MODEL-1301D)に取り付け, $5 \mathrm{~mm} / \mathrm{min}$ の試験速度で行い, 各々 の引張強さと $95 \%$ の信頼区間を求めた.

\section{3 曲計訊験}

試験片は，引張試験で使用する試験片と同じ物から機械加 工によって作製した. Fig.2に作製した平板状の試験片写真を 示す. 各部分の寸法は, 長さが $80 \mathrm{~mm}$, 幅が $10 \mathrm{~mm}$, 厚さが $3 \mathrm{~mm}$ である.

作製した試験片をJIS K 7171 プラスチック-曲げ特性の試 験方法を参考に試験を行った. 個数は, 各設定温度に対し 5 個である. 引張試験同様, 荷重測定機(AIKOH ENGINEERING, MODEL-1301D)に取り付け，曲げ試験用の治具を用いて行っ た. 試験速度は $5 \mathrm{~mm} / \mathrm{min}$, 支点間距離 $48 \mathrm{~mm}$ である. 各々の 曲げ強さと $95 \%$ の信頼区間を求めた。

\section{3. 実験結果および考察}

\section{1 試験片外観}

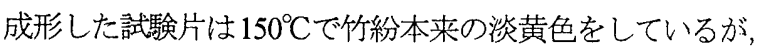
成形温度が高くなるにつれ褐色が強くなり， $240^{\circ} \mathrm{C} か ゙$ 特に褐色 が強くなった.このことから $180^{\circ} \mathrm{C}$ と $240^{\circ} \mathrm{C}$ の間で熱分解が進 み，炭化によって褐色になったと思われる．また，維管束鞘 と柔細胞が分かれていることが観察できる，成形温度が高く なるにつれ，維管束鞘は小さくなり，柔細胞との境が明確で

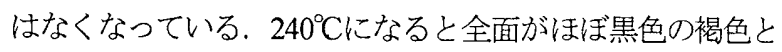
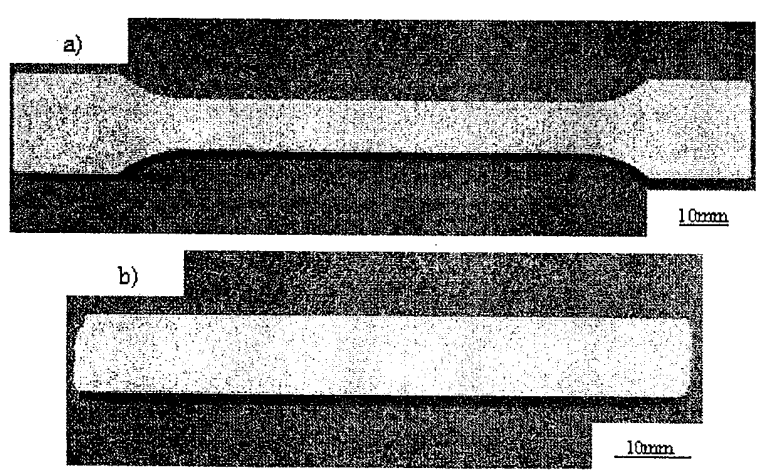

Fig.2 Photographs of specimen
a) tension specimen
b) flexural specimen 
なり, 維管束鞘と柔細胞の境はまったく見ることができない． 3.2 引張強度特性

Fig.3 にマイクロスコープで撮影した試験後の破面写真 $\left(150^{\circ} \mathrm{C}\right.$ と $\left.240^{\circ} \mathrm{C}\right)$ を示す. $150^{\circ} \mathrm{C} て ゙ は$ 維管束鞘のプルアウト が顕著に現れていることがわかる. 成形温度が高くなるとプ ルアウトが減っており，240Cでは見られなくなっている．以 上のことから，低温の成形温度では熱分解が活発に行われて おらず，維管束鞘および柔細胞の結合も不完全であると考え られる.

Fig.4 に引張強さおよびヤング率と成形温度との関係を示 す. どちらとも成形温度が高くなるほど, 大きくなっている. 最も大きい值は, 引張強さが $17.94 \mathrm{MPa}$, ヤング率が $57.60 \mathrm{MPa}$ である．竹の細胞壁の主な構成成分は，セルロース，人ミセ ルロース, リグニンである. 熱分解はそれぞれ $240^{\circ} \mathrm{C}, 180^{\circ} \mathrm{C}$, $260^{\circ} \mathrm{C}$ 程度から盛んに行われると言われている，このため，成 形温度 $180^{\circ} \mathrm{C}$ 付近からへミセルロースの熱分解が盛んに行わ れた。これにより，接着剤を添加せずに自己接着性による接 着，バインダレス接着を起こしたため，熱分解がより進んだ 高温の成形温度の方が, 引張強さ，およびヤング率が共に高 くなったと考えられる.

\section{3 曲強度特性}

Fig.5 に曲げ強さおよび曲げ弾性率と成形温度との関係を 示寸．曲げ試験でも成形温度が高くなると，曲げ強さ，曲げ 弾性率，どちらも值が大きくなった，最も大きい值は，曲げ 強さが 29.27MPa，曲げ弾性率が 110.40MPa である.

\section{4 プラスチックとの比較}

今回作製した竹紛成形体において，最大の引張強さは 17.94MPa であった.これに対してポリエチレン PE は 11.77 〜37.27MPa，ポリプロピレン PPは29.42〜39.23MPa，ポリア セタールPOMは68.65MPaである ${ }^{1)}$. 竹粉を用いた成形体は,
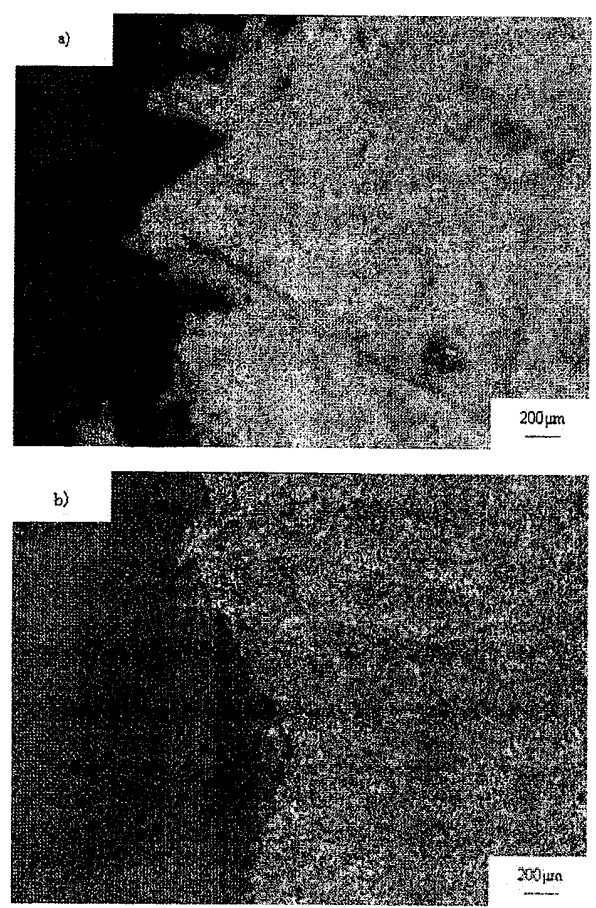

Fig.3 Photographs of fracture behavior
a) $150^{\circ} \mathrm{C}$
b) $240^{\circ} \mathrm{C}$

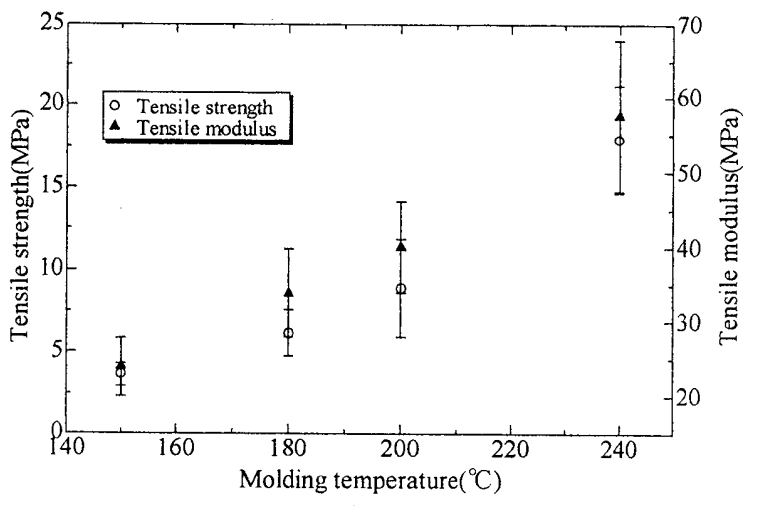

Fig.4 Relationship between tensile properties and molding temperature

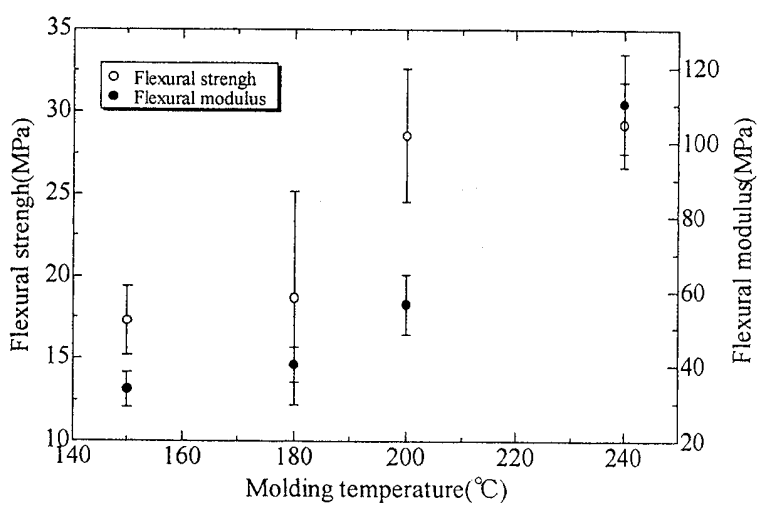

Fig.5 Relationship between flexural properties and molding temperature

工業方面で使われるポリアセタールと比較すると見劣りする. しかし，日常で触れる頻度の高いポリエチレンとは值が拮抗 している.このことから，今後の発展によっては竹粉プレス 成形体が日用雑貨の材料として, 活用の可能性があると考え られる。

\section{4. 結言}

本研究では，プラスチックの代替材料として，竹が工業資 源として有用かを調查することが目的である.引張強度特性, 曲げ強度特性の調查および，プラスチックの強度特性とも比 較を行った．また，竹粉の成形は本研究のどの温度でも作製 ができた。以下に調查結果を示す。

1）引張強さ, ヤング率, 曲げ強さ, 曲げ弾性率は全て, 成 形温度が高くなるほど大きくなることがわかった。

2）本研究の成形条件では，へミセルロースの熱分解が試験 片作成に大きく関わってくることがわかった，また，試 験片の密度は，成形温度が高くなるほどに大きくなった。 ヘミセルロースの熱分解が盛んに行われるほど，竹粉の 流動性の向上により高くなることもわかった.

3）今すぐにプラスチックにとって代わることはできない が，竹はその可能性を有することがわかった。

\section{参考文献}

1）松崎啓, 佐倉武久, 山田準吉: 日本科学会編産業科学シ リーズ・プラスチック, (1974), 巻末付表, 大日本図書 株式会社 